\title{
Economic Analysis of Grafted Tomato Production in Sandy Soils in Northern Florida
}

\author{
Desire Djidonou ${ }^{1,3}$, Zhifeng $\mathrm{Gao}^{2,4}$, and Xin Zhao ${ }^{1,5,6}$
}

ADDITIONAL INDEX wORDs. break-even price, grafting, net return, partial budget analysis, profitability, sensitivity analysis

SUMMARY. In addition to controlling soilborne diseases, grafting with selected rootstocks has the potential to enhance growth and yields in tomato (Solanum lycopersicum) production. However, information is rather limited regarding its economic viability in different production systems in the United States. The objective of this study was to compare the costs and returns of grafted vs. nongrafted fresh-market tomato production under common management practices in fumigated fields in northern Florida. The field trials were conducted in Live Oak, FL, during Spring 2010 and 2011. 'Florida 47' tomato was grafted onto two interspecific hybrid tomato rootstocks: 'Beaufort' and 'Multifort'. Grafted and nongrafted 'Florida 47' plants were grown on fumigated raised beds with polyethylene mulch and drip irrigation using recommended commercial production practices for nutrient and pest management. The estimated costs of grafted and nongrafted transplants were $\$ 0.67$ and $\$ 0.15$ per plant, respectively, resulting in an additional cost of $\$ 3020.16$ per acre for using grafted transplants as compared with nongrafted plants. Grafting also led to higher costs of harvesting and marketing tomato fruit as a result of yield improvement (1890 to 2166 25-1b cartons per acre for grafted plant vs. 1457 to 152625 -lb cartons per acre for nongrafted plant). Partial budget analyses showed that using grafted transplants increased tomato production costs by $\$ 4488.03-\$ 5189.76$ per acre depending on the rootstock and growing season. However, compared with nongrafted tomato, the net farm return of grafted tomato production was increased by $\$ 253.32-\$ 2458.24$ per acre based on the tomato shipping point prices. Sensitivity analysis further demonstrated that grafting would be more profitable as the costs of grafted transplants decreased and the market tomato prices increased. These results indicated that although grafting increased the total cost of production, the increase in marketable fruit yield generated significant gross returns to offset costs associated with the use of grafted tomato transplants. Nevertheless, further research is warranted to provide more production budget and net return data about the economic feasibility of grafted tomato production based on a wide range of commercial growing conditions in Florida.

$\mathrm{T}$ o date, grafting has been used successfully in vegetable production for disease control and yield improvement in many parts of the world, especially in Asia and Europe (Lee and Oda, 2003; Lee et al., 2010). A number of rootstocks have been developed for managing various soilborne diseases and root-knot nematodes in production of tomato, eggplant

This project was supported in part by a Southern Region Sustainable Agriculture Research and Education (SARE) Graduate Student Grant (GS10-097) awarded to Desire Djidonou. It was also funded in part by a USDA Specialty Crop Research Initiative grant (2011-51181-30963).

${ }^{1}$ Horticultural Sciences Department, University of Florida, Gainesville, FL 32611

${ }^{2}$ Food and Resource Economics Department, University of Florida, Gainesville, FL 32611

${ }^{3}$ Graduate Research Assistant

${ }^{4}$ Assistant Professor

${ }^{5}$ Associate Professor

${ }^{6}$ Corresponding author. E-mail: zxin@ufl.edu.
(Solanum melongena), pepper (Capsicum annuum), cucumber (Cucumis sativus), melon (Cucumis melo), and watermelon (Citrullus lanatus), particularly in intensive cultural systems (King et al., 2010; Lee et al., 2010; Louws et al., 2010). Moreover, many of these rootstocks demonstrate tolerance to abiotic stresses and show great potential for enhancing crop vigor and productivity even under low disease pressure (Di Gioia et al., 2010; Fernández-García et al., 2002; Schwarz et al., 2010). In the United
States, greenhouse hydroponic tomato growers are currently the primary users of grafted seedlings, whereas vegetable grafting is still a relatively new technique for open-field producers (King et al., 2010; Kubota et al., 2008; Lee et al., 2010).

With the phaseout of methyl bromide soil fumigant and new search for integrated disease management practices in field vegetable production, interest in vegetable grafting under field conditions has been growing recently in the United States (Barrett et al., 2012a; Kubota et al., 2008; Rivard et al., 2010a; Rivard and Louws, 2008). However, the high cost of grafted transplants still remains the major concern limiting the adoption of grafting by vegetable growers, especially large-scale open-field producers (Kubota et al., 2008; Lee et al., 2010). In addition to the costs of rootstock seeds, grafted transplant production requires investment in space, supplies and materials, and labor for making and healing the grafts, which ultimately increases the costs of grafted vegetable production (Barrett et al., 2012b; Rivard et al., 2010b). For example, estimated prices for grafted tomato transplants ranged from $\$ 0.59$ to $\$ 1.88$ as opposed to $\$ 0.13$ to $\$ 0.76$ for nongrafted plants in two transplant production operations in the United States (Rivard et al., 2010b).

A recent study on grafted heirloom tomato production demonstrated the economic feasibility of using grafted plants for root-knot nematode control when there was a high level of infestation in the field (Barrett et al., $2012 b$ ). However, limited information is available as to whether grafting can be used economically in openfield production. Considering the multifaceted benefits of vegetable grafting, a comprehensive approach involving different production scenarios is needed to evaluate the economic feasibility of using grafted tomato transplants as a viable component of field tomato production systems.

\begin{tabular}{llll}
\hline $\begin{array}{l}\text { Units } \\
\text { To convert U.S. to SI, } \\
\text { multiply by }\end{array}$ & U.S. unit & SI unit & $\begin{array}{l}\text { To convert SI to U.S., } \\
\text { multiply by }\end{array}$ \\
\hline 0.4047 & $\mathrm{acre}(\mathrm{s})$ & $\mathrm{ha}$ & 2.4711 \\
0.3048 & $\mathrm{ft}$ & $\mathrm{m}$ & 3.2808 \\
9.3540 & $\mathrm{gal} / \mathrm{acre}$ & $\mathrm{L} \cdot \mathrm{ha}^{-1}$ & 0.1069 \\
2.54 & inch $(\mathrm{es})$ & $\mathrm{cm}$ & 0.3937 \\
0.4536 & $\mathrm{lb}$ & $\mathrm{kg}$ & 2.2046 \\
1.1209 & $\mathrm{lb} / \mathrm{acre}$ & $\mathrm{kg} \cdot \mathrm{ha}^{-1}$ & 0.8922
\end{tabular}

Hortlechnology · October $201323(5)$ 
The main objective of this 2-year study was to determine the costs and benefits of using grafted transplants for field production of fresh-market tomato in fumigated sandy soils in northern Florida. A partial budget analysis of grafted vs. nongrafted tomato production was performed to assess if the additional costs associated with grafting can be offset by the improved marketable fruit yield. In addition, given that grafted transplant prices may decrease as research advances and the profitability of tomato production is also determined by tomato market prices, sensitivity analyses were conducted to examine the net returns of grafted tomato production as influenced by the grafted transplant costs and tomato selling prices.

\section{Materials and methods}

FIELD PRODUCTION OF FRESHMARKET TOMATO. Field experiments were carried out during Spring 2010 and 2011 growing seasons at the Suwannee Valley Agricultural Extension Center in Live Oak, FL (lat. $30.31^{\circ} \mathrm{N}$, long. $82.90^{\circ} \mathrm{W}$ ) on a Blanton-Foxworth-Alpin Complex sandy soil. The field-grown determinate tomato cultivar Florida 47 (Seminis Vegetable Seeds, St. Louis, MO) was used as scion and was grafted onto two commercially available interspecific tomato hybrid rootstocks 'Beaufort' (FL/BE) and 'Multifort' (FL/ MU) (De Ruiter Seeds, Bergschenhoek, The Netherlands). The nongrafted 'Florida 47' (FL) was used as a control, representing current commercial production practices. The two rootstocks used in this study are among the most widely used tomato rootstocks in the United States at present. Scion seeds were planted on $23 \mathrm{Feb}$. 2010 and 21 Feb. 2011, 2 d after sowing the rootstock seeds. Tomato plants were grafted on 16 Mar. 2010 and 20 Mar. 2011 (Djidonou et al., 2013). In both years, 5 weeks before transplanting, field plots were disked and plowed, followed by soil fumigation using 1,3-dichloropropene + chloropicrin (Telone C-35; Dow AgroSciences, Indianapolis, IN) at the rate of $21.0 \mathrm{gal} / \mathrm{acre}$ a.i. Grafted and nongrafted plants were transplanted in raised beds with plastic mulch and drip irrigation on 29 Mar. 2010 and 1 Apr. 2011. Beds were 28 inches wide and spaced $5 \mathrm{ft}$ apart with 18-inch inrow spacing for open-field tomato production, resulting in 5808 plants per acre. In both seasons, a randomized complete block design with four replications (blocks) was used. Plants were grown following the current University of Florida/Institute of Food and Agricultural Sciences recommendation for irrigation and fertilization program for commercial tomato production (Olson et al., 2009). The total fertilizer application rates were 200 $\mathrm{lb} /$ acre nitrogen, $6.5 \mathrm{lb} /$ acre phosphorus, and $183 \mathrm{lb} /$ acre potassium (Djidonou et al., 2013). Plants were trained using the standard stake and weave system. Tomato fruit that reached mature green or more advanced ripening stages were harvested at 80 and $88 \mathrm{~d}$ after transplanting (DAT) in 2010 and at 75,85 , and 92 DAT in 2011. Fruit were graded as extra large, large, medium, and culls (small fruit and defected fruit), and the tomato fruit in each grade were counted and weighed. Marketable fruit yield was then calculated as the total weight of extra-large, large, and medium fruit and was expressed as number of 25-lb cartons per acre.

COSTS OF GRAFTED AND NONGRAFTED TRANSPLANT PRODUCTION. In this study, the costs of grafted and nongrafted transplants were estimated following the procedure described by Barrett et al. (2012b). All the materials, supplies, and labor associated with the production of grafted and nongrafted transplants were estimated to calculate the costs of nongrafted 'Florida 47' plants and grafted 'Florida 47' plants with 'Beaufort' or 'Multifort' rootstock.

BASE PRODUCTION COST MODEL FOR OPEN-FIELD PRODUCTION OF FRESH-MARKET TOMATO. For the purpose of this study, a base cost model for growing, harvesting, and marketing 'Florida 47' in a 1-acre field with a raised-bed polyethylene mulch production system was established using an existing crop budget model for fresh tomato production in the Manatee/Ruskin, FL area developed by the University of Florida Center for Agribusiness (2009). Costs of production inputs, including transplants and fertilizers during the 2010 and 2011 trials, were estimated and used in developing the actual production budget in this study. The variable costs of irrigation were estimated based on information provided by Pitts et al. (2002). A harvest and marketing charge of $\$ 3.39$ per $25-1 b$ carton (derived from the existing crop budget model described above) was used to estimate the harvest and marketing costs for total marketable tomato yields in 2010 and 2011, which included costs of containers, harvesting and hauling, packing, selling, and organization fees. The tomato shipping point prices of $\$ 10.95$ (2010) and \$11.95 (2011) per 25-lb carton during the harvest periods [U.S. Department of Agriculture (USDA), 2011)] were used in calculating the gross returns (crop value) of grafted and nongrafted tomato production.

Partial budget analysis of GRAFTED AND NONGRAFTED TOMATO PRODUCTION. Partial budget analysis is a standard economic analysis tool commonly used to determine the effects of a series of changes to certain operations of the farming production system on the change of returns (Sydorovych et al., 2008). This economic analysis approach compares the negative and positive effects of applying a new treatment relative to a base or standard treatment. It can provide a brief overview on the possible economic advantage that may accrue to growers adopting the new production practice. In the context of this study, using grafted tomato transplants is considered as the new treatment, whereas using nongrafted transplants is the standard practice. The typical components of partial budget analysis as presented by Sydorovych et al. (2008) were adapted as follows: 1) negative effects: added costs due to grafting, reduced returns due to grafting, and total negative effects due to grafting (i.e., the summation of added costs and reduced returns);2) positive effects: reduced costs due to grafting, added returns due to grafting, and total positive effects due to grafting (i.e., the summation of reduced costs and added returns); and 3 ) total effect (i.e., net change in revenue): difference between total positive effects and total negative effects.

It was assumed that added costs of grafted tomato production relative to the nongrafted tomato production would be incurred if the costs of grafted transplants and the harvest costs of grafted plants were higher than the transplant and harvest costs of nongrafted tomato production. Furthermore, added returns would be incurred if the use of grafted plants resulted in 
higher yields, larger fruit size, and improved fruit quality, which means higher gross returns in grafted tomato production than in nongrafted tomato production.

Sensitivity analysis. Freshmarket tomato prices fluctuate constantly within and across seasons. The sensitivity analysis was conducted to evaluate the effects of changes in the fresh-market tomato prices and grafted transplant costs on the net returns of grafted tomato production for each of the two production seasons. The analysis was performed for each grafting type using different combinations of scenarios involving variations in tomato prices (i.e., $\$ 8.95, \$ 10.95$, $\$ 11.95, \$ 13.95$, and $\$ 14.65$ per 25 lb carton) and grafted transplant costs $(\$ 0.84, \$ 0.67, \$ 0.54, \$ 0.43$, and $\$ 0.34$ per plant). The tomato prices were selected from the reported shipping point prices of mature green tomatoes per $25-\mathrm{lb}$ carton in the past 7 years (USDA, 2011). Because lower tomato prices may lead to a more significant reduction in net returns of grafted tomatoes than nongrafted tomatoes, and the focus of the present study was to determine the economic feasibility of grafted tomatoes, only one lower price $(\$ 8.95)$ and two higher prices $(\$ 13.95$ and $\$ 14.65)$ than the $2010(\$ 10.95)$ and 2011 (\$11.95) base prices were used. In addition, because lower costs of grafted transplants will conceivably make grafted tomato production more economically feasible, one higher cost and three lower costs of grafted transplants than the base cost $(\$ 0.67)$ of grafted transplants were included. The cost levels of grafted transplants were determined by decreasing the highest cost $(\$ 0.84)$ by $20 \%$ gradually. At different tomato prices, the break-even analysis was also conducted to estimate the grafted transplant cost at which grafted and nongrafted tomato production would result in the same net returns when the nongrafted transplant cost was assumed to be fixed at the base level of $\$ 0.15 /$ plant.

\section{Results and discussion}

Costs OF TOMATO TRANSPLANT PRoDUCtion. Grafting involves the combination of two plants with distinctive traits to form a new plant. Hence, the use of grafted tomato transplants will result in additional costs inherent to materials, space, and labor needed for grafting. In this study, the cost associated with the production of 'Florida 47' grafted onto either 'Beaufort' or 'Multifort' was estimated at $\$ 0.67 /$ plant vs. $\$ 0.15 /$ plant for the nongrafted transplants (Table 1 ). On a per plant basis, our estimations showed that the grafted tomato transplant was $347 \%$ more expensive than the nongrafted plant. Such a price difference was consistent with that reported by Barrett et al. (2012b) on grafted organic heirloom tomato transplants using the 'Multifort' rootstock. Similarly, estimated costs were $\$ 0.59$ and $\$ 0.13$ per plant for grafted and nongrafted tomato transplants, respectively, in a commercial farming operation in North Carolina (Rivard et al., 2010b). In contrast, Besri (2003) reported only a 1 -fold increase of tomato transplant price with grafting in Morocco (i.e., $\$ 0.19$ and $\$ 0.38$ per plant for nongrafted and grafted tomato transplants, respectively). Costs of grafted vegetable transplants also vary with the crop type. According to Taylor et al. (2008), the price of grafted seedless watermelon transplants was $\$ 0.87 /$ plant as compared with $\$ 0.28 /$ plant for nongrafted transplants. As indicated in the previous studies, the higher cost of rootstock seeds, rather than the labor costs of grafting operation, is often the main contributing factor to the increased costs of grafted plants. In the present study, the material cost accounted for $\approx 73 \%$ of the total costs of grafted transplant production. With the development of more rootstock breeding programs in the United States, it is anticipated that the rootstock seed price may decrease, thus reducing the cost of grafted transplants. Advancement in grafting techniques, including automation of the grafting operation, may also help lower

Table 1. Estimated costs of nongrafted 'Florida 47' tomato transplants and 'Florida 47' transplants grafted onto 'Beaufort' or 'Multifort'.

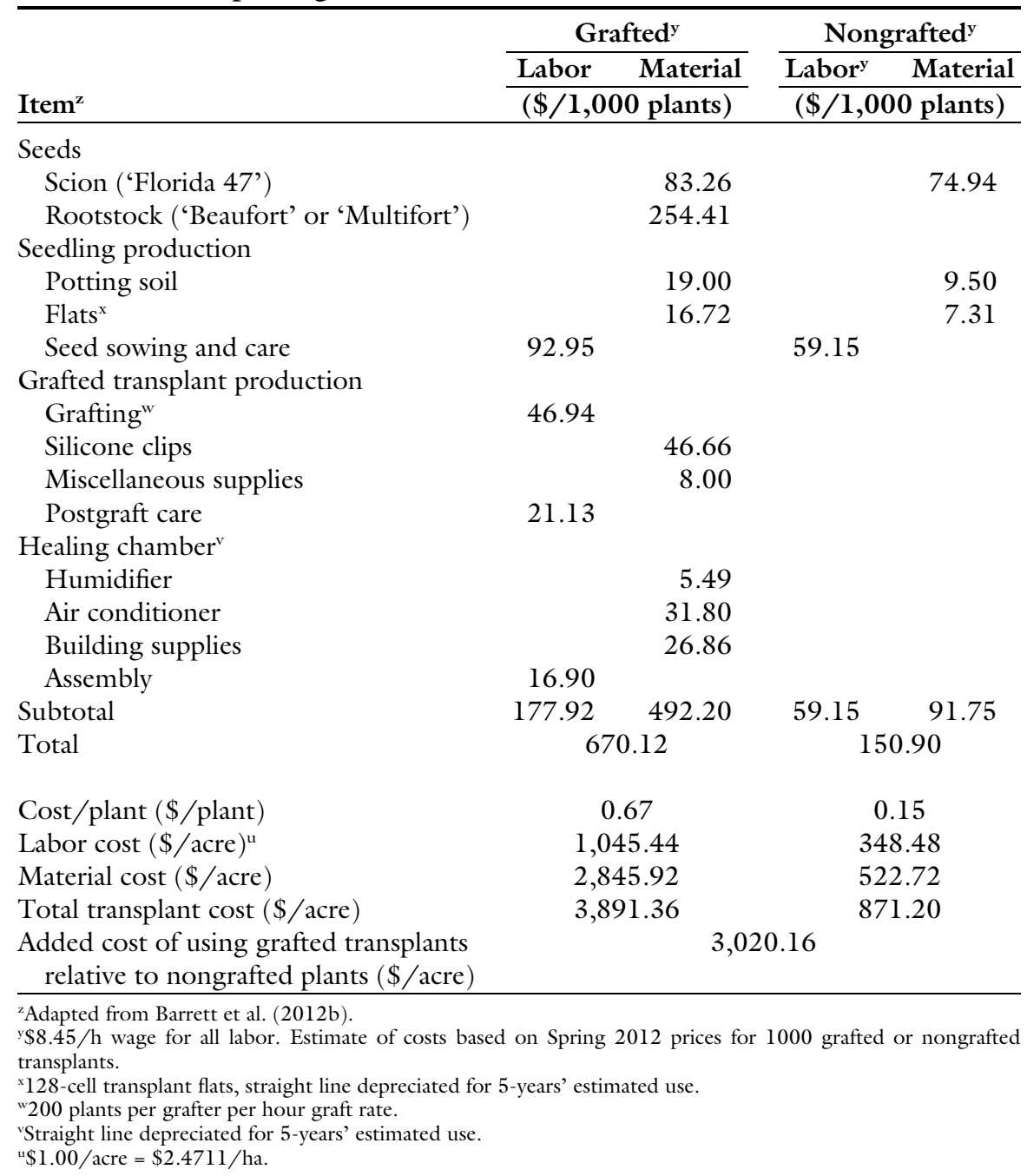


the cost of grafted transplant production (Lee et al., 2010).

With the planting density of 5808 tomato plants per acre used in this study, grafting with either 'Beaufort' or 'Multifort' rootstocks added about $\$ 3020.16$ per acre to the total preharvest production costs in field production of 'Florida 47' (Table 1 ). This was in line with the report of grafted transplant costs in North Carolina, which indicated that the use of grafted tomato transplants would increase the production costs by $\$ 2275$ per acre (O'Connell et al., 2009).

COSTS OF FIELD PRODUCTION OF FRESH-MARKET TOMATO. In this study, the total costs per acre required to produce, harvest, and market 'Florida 47' tomatoes in the area of Live Oak, FL, using the raised-bed polyethylene mulch system with drip irrigation were estimated at $\$ 14,720.77$ and $\$ 14,954.68$ in Spring 2010 and 2011 production seasons, respectively ( $\mathrm{Ta}-$ ble 2). Our estimated total production costs were slightly lower than the budget of $\$ 15,451.77$ per acre developed by the University of Florida Center for Agribusiness (2009). Such differences were expected as our production budget accounted for the estimated costs of transplants, irrigation, and nutrient management during the field trials. In addition, the harvest costs estimated in our study reflected the marketable yields of nongrafted tomatoes measured in the 2010 and 2011 field trials. The total estimated costs of field tomato production in the present study were also comparable to the estimated cost of $\$ 16,926$ per acre for producing and harvesting tomatoes in fumigated soils in North Carolina (Sydorovych et al., 2008).

These total estimated costs involved the variable and fixed costs associated with the preharvest operations and the costs needed for harvest and marketing. Specifically, the preharvest operational costs included the costs associated with transplants, irrigation, fertilization, and other management practices, which made up $\approx 66 \%$ of the total production costs. The harvest and postharvest operations, including packaging and marketing tomatoes, amounted to $\$ 4939.23$ per acre and $\$ 5173.14$ per acre in 2010 and 2011, respectively (Table 2 ).

MARKeTABle FRUIT YIELD AND GROSS RETURNS. In this study, yield increases as a result of grafting with interspecific rootstocks were demonstrated in both the 2010 and 2011 field trials. In 2010, the average marketable yields were 2024 and 1890 25 -lb cartons per acre with 'Florida 47 ' grafted onto 'Beaufort' (FL/BE) and 'Multifort' (FL/MU), respectively, as opposed to 1457 cartons per acre for the nongrafted plants (Table 3). In 2011, these values were 2166,2138 , and 1526 cartons per acre for $\mathrm{FL} / \mathrm{BE}, \mathrm{FL} / \mathrm{MU}$, and $\mathrm{FL}$, respectively. As a result, projected total harvest costs were higher with the grafted treatments as compared with the nongrafted 'Florida 47 ' during the two production seasons. For example, in 2010, the harvest cost of nongrafted 'Florida 47' was $\$ 4939.23$, whereas the estimated harvest cost was $\$ 6861.36$ in grafted tomato production with 'Beaufort' (Table 3).

Table 2. Estimated costs per acre needed to produce, harvest, and market 'Florida 47' tomatoes in field production with raised-bed polyethylene mulch system in Spring 2010 and 2011 growing seasons in Live Oak, FL.

\begin{tabular}{|c|c|c|c|c|}
\hline & 2010 & 2011 & 2010 & 2011 \\
\hline Operation $^{z}$ & \multicolumn{2}{|c|}{$(\$ / \text { acre })^{y}$} & \multicolumn{2}{|c|}{$\overline{(\$ / 25-1 b \text { carton })^{y}}$} \\
\hline
\end{tabular}

Fertilizer and irrigation costs

Fertilizer

Irrigation tubing

Pumping cost

Labor cost

Total fertilizer and irrigation cost

Operating costs

Transplants

Fumigant

Fungicide

Herbicide

Insecticide

General farm labor (includes tractor driver wages)

Machinery variable cost

Miscellaneous costs

Tie plants

Scouting

Plastic mulch

Stakes

Plastic string

String, stake, and mulch disposal

Farm vehicles

Interest on operating capital

Total operating costs

Fixed costs

Land rent

Machinery fixed cost

Farm management and overhead

Total fixed cost

Total preharvest cost

Harvest and marketing costs

Tomato carton

Sell

Pack

Harvest and haul

Organization fees

Total harvest and marketing cost

Total cost
617.61

107.50

8.59

12.77

746.47

871.20

675.00

264.45

45.35

520.17

560.39

$1,095.28$

145.20

35.00

330.00

112.00

100.00

342.80

33.34

296.21

$6,172.86$

300.00

235.94

$3,072.74$

$3,608.68$

$9,781.54$

$1,092.75$

218.55

$2,404.05$

$1,092.75$

131.13

$4,939.23$

$14,720.77$
617.61

107.50

8.59

12.77

746.47

871.20

675.00

264.45

45.35

520.17

186.62

$1,095.28$

145.20

35.00

330.00

112.00

100.00

342.80

33.34

296.21

$6,172.86$

300.00

235.94

$3,072.74$

$3,608.68$

$9,781.54$

6.71

6.41

$1,144.50$

228.90

0.75

0.15

0.75

2,517.90

1.65

0.15

$1,144.50$

0.75

137.34

0.09

0.75

0.09

$5,173.14$

3.39

3.39

$14,954.68$

10.10

9.80

${ }^{2}$ Costs of fertilizer, irrigation, and other preharvest operations for a 1 -acre ( 0.4 ha) tomato field were calculated based on information provided by suppliers, estimated irrigation costs for tomato production in Florida (Pitts et al., 2002), and estimated production costs in the Manatee/Ruskin, FL, area in 2008-09 (University of Florida Center for Agribusiness, 2009).

${ }^{\mathrm{y}} \$ 1.00 / \mathrm{acre}=\$ 2.4711 / \mathrm{ha} ; \$ 1.00 / 25-\mathrm{lb}(11.3 \mathrm{~kg})$ carton $=\$ 0.0882 / \mathrm{kg}$. 
Table 3. Average marketable tomato fruit yields, harvest costs, and gross returns for nongrafted and grafted 'Florida 47' in field production with raised-bed polyethylene mulch system during Spring 2010 and 2011 in Live Oak, FL.

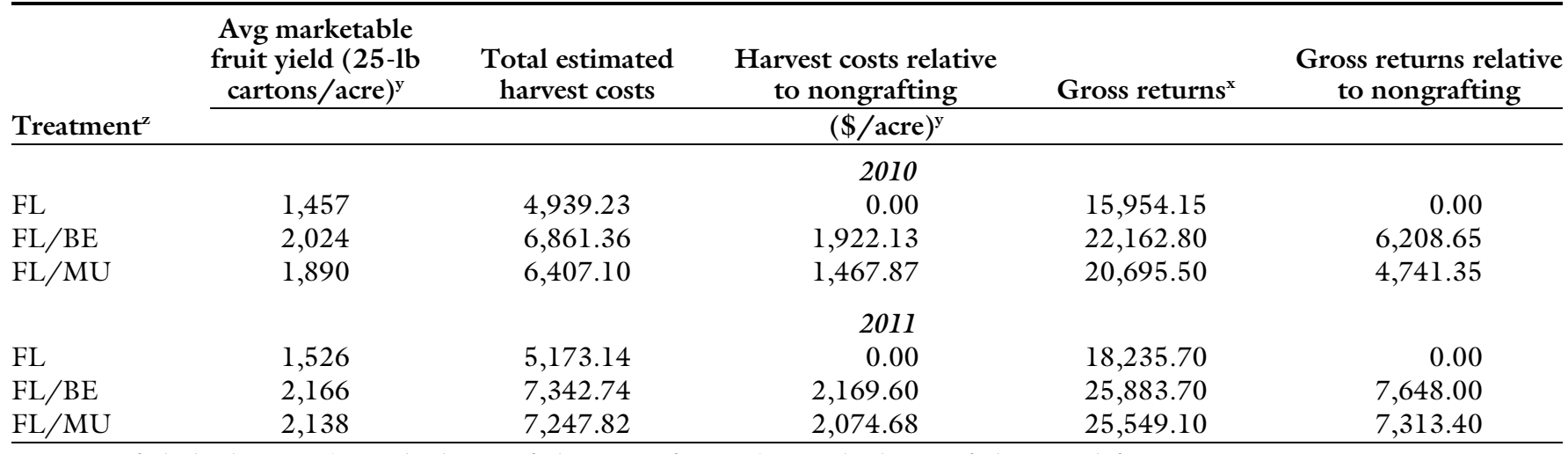

${ }^{2} \mathrm{FL}=$ nongrafted 'Florida 47'; FL/BE = 'Florida 47' grafted onto 'Beaufort'; FL/MU = 'Florida 47' grafted onto 'Multifort'.

${ }^{y} 125-\mathrm{lb}(11.3 \mathrm{~kg})$ carton $/$ acre $=28.0213 \mathrm{~kg} \cdot \mathrm{ha}^{-1} ; \$ 1.00 /$ acre $=\$ 2.4711 / \mathrm{ha}$.

${ }^{x}$ The tomato selling (shipping point) prices of $\$ 10.95$ (2010) and $\$ 11.95$ (2011) per 25-lb carton (USDA, 2011) were used in calculating the gross returns of grafted and nongrafted tomato production; $\$ 1.00 / 25-\mathrm{lb}$ carton $=\$ 0.0882 / \mathrm{kg}$.

The tomato selling (shipping point) prices of $\$ 10.95$ (2010) and $\$ 11.95$ (2011) per 25-lb carton during the harvest periods (USDA, 2011) were used in calculating the gross returns (crop value) of grafted and nongrafted tomato production. In 2010 , the gross returns reached $\$ 22,162.80$ and $\$ 20,695.50$ per acre for production of grafted 'Florida 47' with 'Beaufort' and 'Multifort', respectively (Table 3 ). In contrast, the nongrafted tomato production was valued at $\$ 15,954.15$ per acre. Hence, the additional gross returns relative to nongrafting were $\$ 6208.65$ and $\$ 4741.35$ per acre for 'Beaufort' and 'Multifort', respectively. In 2011, these additional gross returns were $\$ 7648.00$ and $\$ 7313.40$ per acre for 'Beaufort' and 'Multifort', respectively (Table 3). The gross returns were slightly higher in 2011 than in 2010 because of higher marketable fruit yields achieved in the 2011 season. A previous study of 'Florida 47' production in Live Oak, FL, showed the gross returns of $\$ 19,972$ and $\$ 10,736$ per acre in Spring 2005 and 2006 growing seasons, respectively (Gazula, 2009). These results indicated that the gross returns of field tomato production could vary considerably depending on seasonal changes of fruit yields and market tomato prices.

Partial budget analyses of GRAFTED TOMATO PRODUCTION. Typically, partial budget analysis describes the negative and positive effects associated with the use of alternative inputs or production practices. In terms of the production costs, the negative effects (added costs) related to the use of grafted transplants involved the increased costs of transplants and the harvest. These total negative effects amounted to $\$ 4942.29$ and $\$ 4488.03$ per acre with grafting 'Florida 47' onto 'Beaufort' and 'Multifort', respectively, in 2010; and $\$ 5189.76$ and $\$ 5094.84$ per acre in 2011 (Table 4 ). On the other hand, the positive effects associated with grafted transplants involved the added returns on the tomato fruit values, which ranged from $\$ 4741.35$ to $\$ 7648.00$ per acre over the two production seasons (Table 4).

The net return can be estimated as the difference between the gross returns and production costs. The transplant and harvest costs changed as a result of using grafted transplants, whereas other production costs remained constant regardless of the use of grafted transplants. The net return for each grafted treatment relative to the nongrafted treatment can also be calculated as the difference between the total positive effects of grafting and the total negative effects of grafting. After accounting for grafting and harvest

Table 4. Added costs and reduced returns, total negative effects, reduced costs and added returns, and total positive effects incurred by grafting 'Florida 47' tomato onto 'Beaufort' and 'Multifort' rootstocks in field production with raised-bed polyethylene mulch system during Spring 2010 and 2011 growing seasons in Live Oak, FL.

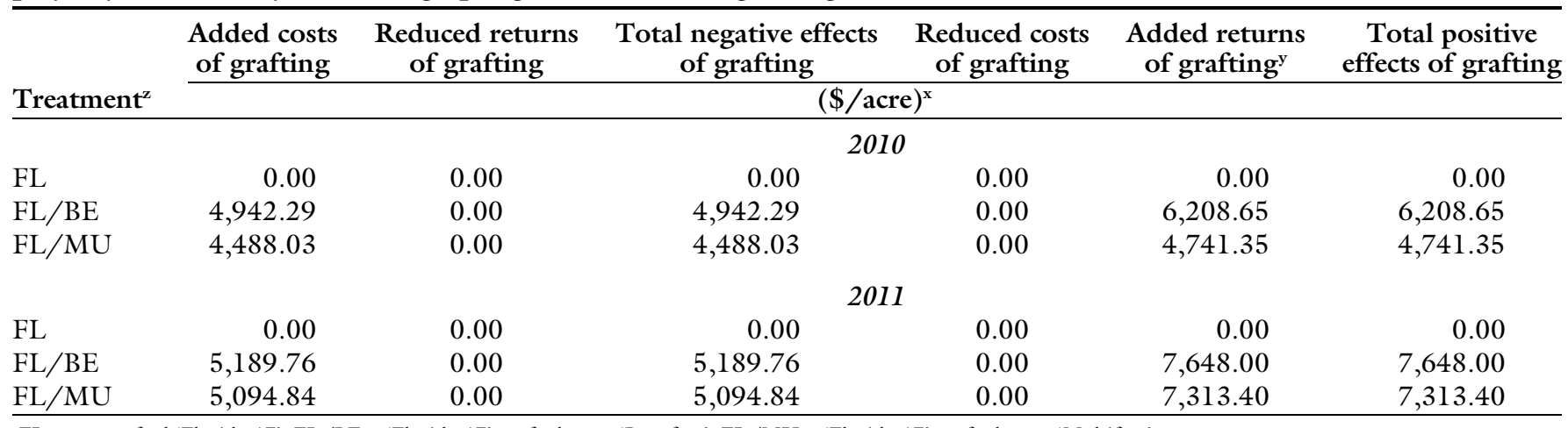

${ }^{\mathrm{z}} \mathrm{FL}$ = nongrafted 'Florida 47'; FL/BE = 'Florida 47' grafted onto 'Beaufort'; FL/MU = 'Florida 47' grafted onto 'Multifort'.

yThe tomato selling (shipping point) prices of $\$ 10.95$ (2010) and $\$ 11.95$ (2011) per $25-\mathrm{lb}$ (11.3 kg) carton (USDA, 2011) were used in calculating the gross returns of grafted and nongrafted tomato production; $\$ 1.00 / 25-\mathrm{lb}$ carton $=\$ 0.0882 / \mathrm{kg}$.

× $1.00 /$ acre $=\$ 2.4711 /$ ha. 
Table 5. Comparisons of estimated gross returns; costs of transplants, harvest, and other production and operations; and total net returns between field production of grafted and nongrafted 'Florida 47' tomato in Live Oak, FL.

\begin{tabular}{|c|c|c|c|c|c|c|}
\hline \multirow[b]{2}{*}{ Treatment $^{\mathrm{z}}$} & $\begin{array}{c}\text { Gross } \\
\text { returns }^{\mathrm{y}}\end{array}$ & $\begin{array}{l}\text { Transplant } \\
\text { costs }\end{array}$ & $\begin{array}{c}\text { Harvest } \\
\text { costs }\end{array}$ & $\begin{array}{l}\text { Other production } \\
\text { and operation costs }\end{array}$ & Total net returns & $\begin{array}{l}\text { Additional net returns } \\
\text { relative to nongrafting }\end{array}$ \\
\hline & \multicolumn{6}{|c|}{$(\$ / \text { acre })^{\mathrm{w}}$} \\
\hline & \multicolumn{6}{|c|}{2010} \\
\hline FL & $15,954.15$ & 871.20 & $4,939.23$ & $8,910.34$ & $1,233.38$ & 0.00 \\
\hline $\mathrm{FL} / \mathrm{BE}$ & $22,162.80$ & $3,891.36$ & $6,861.36$ & $8,910.34$ & $2,499.74$ & $1,266.36$ \\
\hline $\mathrm{FL} / \mathrm{MU}$ & $20,695.50$ & $3,891.36$ & $6,407.10$ & $8,910.34$ & $1,486.70$ & 253.32 \\
\hline $\mathrm{FL} / \mathrm{BE}$ & $25,883.70$ & $3,891.36$ & $7,342.74$ & $8,910.34$ & $5,739.26$ & $2,458.24$ \\
\hline $\mathrm{FL} / \mathrm{MU}$ & $25,549.10$ & $3,891.36$ & $7,247.82$ & $8,910.34$ & $5,499.58$ & $2,218.56$ \\
\hline
\end{tabular}

${ }^{\mathrm{z}} \mathrm{FL}=$ nongrafted 'Florida 47'; FL/BE = 'Florida 47' grafted onto 'Beaufort'; FL/MU = 'Florida 47' grafted onto 'Multifort'.

'The tomato selling (shipping point) prices of $\$ 10.95$ (2010) and $\$ 11.95$ (2011) per 25 -lb (11.3 kg) carton (USDA, 2011 ) were used in calculating the gross returns of grafted and nongrafted tomato production; $\$ 1.00 / 25-\mathrm{lb}$ carton $=\$ 0.0882 / \mathrm{kg}$.

${ }^{x}$ The production and operation costs that did not change as a result of using grafted transplants.

w $\$ 1.00 /$ acre $=\$ 2.4711 / \mathrm{ha}$.

costs, the net returns of grafting relative to nongrafting were $\$ 1266.36$ and $\$ 253.32$ per acre for grafted tomato production with 'Beaufort' and 'Multifort', respectively, in the 2010 season (Table 5 ). These relative net returns were \$2458.24 and \$2218.56 per acre in 2011. These values indicated that the increased crop value attributed to the significant improvement of marketable tomato fruit yield could offset the increased cost of grafted tomato production and even made it more profitable than nongrafted tomato production in fumigated soils. In this study, using the rootstock 'Beaufort' appeared to be more cost effective compared with 'Multifort', especially in the 2010 season, because of the higher marketable yield of grafted plants with 'Beaufort'. However, the difference in net returns between grafted and nongrafted tomato production, as observed in the present study, was lower than that reported by O'Connell et al. (2009) in an organic, open-field production of determinate tomato in North Carolina. These authors found that the net return of the top yielding scionrootstock combination, that is, 'Celebrity' grafted onto 'RST-04-105-T', was $\$ 59,635$ per acre as compared with $\$ 8780$ per acre for nongrafted 'Celebrity' tomato. It should be noted that such a great difference in net returns was owing to the high pressure of southern blight (caused by Sclerotium rolfsii). The prevalence of this particular soilborne disease resulted in more than $80 \%$ of dead plants in nongrafted tomato plots within the first 2 weeks of fruit production, whereas the use of resistant rootstock extended fruit production for 7 weeks. Similarly, recent studies on cost-benefit analyses of grafted watermelon (Taylor et al., 2008 ) and heirloom tomato production (Barrett et al., 2012b) indicated that using grafted transplants could be cost effective in the fields with high populations of soilborne pathogens and root-knot nematodes.

Sensitivity analyses. Overall, the change of net returns was dependent on the cost of grafted transplants and the tomato selling prices. For example, in the case of 'Florida 47 ' plants grafted onto 'Beaufort', with the marketable fruit yields achieved in 2010 and the tomato price of $\$ 8.95$ per 25 -lb carton, net returns became negative when the grafted transplant cost was $\$ 0.43 /$ plant or higher (Table $6)$. In contrast, if the cost of grafted transplants was reduced to $\$ 0.34$ / plant, the net return was $\$ 368.38$ per acre. When 'Multifort' was used and at the same tomato selling price, the net return remained negative even with the grafted transplant cost at $\$ 0.34$ / plant (Table 6). It should be noted that with the market tomato price of $\$ 8.95$ per 25 -lb carton, the nongrafted tomato production also led to a negative net return of $\$ 1680.62$ per acre in 2010 using the estimated transplant cost of $\$ 0.15 /$ plant in this study. These results clearly indicate that the financial competitiveness of commercial tomato production could be at risk when the tomato selling price is fixed at $\$ 8.95$ per 25 -lb carton or below, regardless of the type of transplants used. However, with the tomato price of $\$ 13.95$ or higher, grafting with either rootstock would result in consistently higher positive net returns than nongrafted tomato production even when the grafted transplant had a cost of as high as $\$ 0.84$ /plant. As the grafted transplant cost decreases and/or the tomato selling price increases, the margins of net returns of grafted tomato production relative to the nongrafted plants would increase accordingly (Table 6). In addition, the net return was also sensitive to the level of marketable yields achieved. In the 2011 season, with higher marketable yields than in 2010, greater differences in net returns between grafted and nongrafted tomato production were observed. When the tomato selling price was $\$ 10.95$ or higher, grafting with vigorous rootstocks led to consistently higher net returns than nongrafted tomato production even when the grafted transplant cost was the highest at $\$ 0.84$ (Table 7). When negative net returns occurred for nongrafted tomato production at the tomato selling price of $\$ 8.95$, using grafted transplants could reduce the loss of net returns when the transplant cost was at $\$ 0.67$ / plant or lower. For example, at the transplant cost of $\$ 0.54$, the increase in net return as a result of grafting was $\$ 1316.51$ and \$1137.60 per acre with 'Beaufort' and 'Multifort', respectively (Table 7).

Furthermore, estimations of the break-even prices of grafted transplants at which grafted and nongrafted tomato production would lead to the same net return ranged from $\$ 0.56$ to $\$ 1.25$ per plant in 2010 (Table 6) and from $\$ 0.74$ to $\$ 1.39$ per plant in 2011 
Table 6. Estimated net returns of field production of 'Florida 47' tomato grafted onto 'Beaufort' (FL/BE) and 'Multifort' (FL/MU) and the differences in net returns between grafted and nongrafted 'Florida 47' (FL) production with varying tomato prices and grafted transplant costs using the 2010 yield data.

\begin{tabular}{|c|c|c|c|c|c|}
\hline \multirow{3}{*}{$\begin{array}{l}\text { Grafted transplant } \\
\text { cost }(\$ / \text { plant })^{\mathrm{z}}\end{array}$} & \multicolumn{5}{|c|}{ Tomato price $(\$ / 25-1 b \text { carton })^{\mathrm{y}}$} \\
\hline & 8.95 & 10.95 & 11.95 & 13.95 & 14.65 \\
\hline & \multicolumn{5}{|c|}{ Net return: FL/BE $(\$ / \text { acre })^{x}$} \\
\hline 0.84 & $-2,535.62$ & $1,512.38$ & $3,536.38$ & $7,584.38$ & $9,001.18$ \\
\hline 0.67 & $-1,548.26$ & $2,499.74$ & $4,523.74$ & $8,571.74$ & $9,988.54$ \\
\hline 0.54 & -793.22 & $3,254.78$ & $5,278.78$ & $9,326.78$ & $10,743.58$ \\
\hline 0.43 & -154.34 & $3,893.66$ & $5,917.66$ & $9,965.66$ & $11,382.46$ \\
\hline \multirow[t]{2}{*}{0.34} & 368.38 & $4,416.38$ & $6,440.38$ & $10,488.38$ & $11,905.18$ \\
\hline & \multicolumn{5}{|c|}{ Differences between the net return of FL/BE vs. those of FL (\$/acre) } \\
\hline 0.84 & -855.00 & 279.00 & 846.00 & $1,980.00$ & $2,376.90$ \\
\hline 0.67 & 132.36 & $1,266.36$ & $1,833.36$ & $2,967.36$ & $3,364.26$ \\
\hline 0.54 & 887.40 & $2,021.40$ & $2,588.40$ & $3,722.40$ & $4,119.30$ \\
\hline 0.43 & $1,526.28$ & $2,660.28$ & $3,227.28$ & $4,361.28$ & $4,758.18$ \\
\hline 0.34 & $2,049.00$ & $3,183.00$ & $3,750.00$ & $4,884.00$ & $5,280.90$ \\
\hline \multirow[t]{2}{*}{$\mathrm{B} / \mathrm{E}^{\mathrm{w}}$} & 0.69 & 0.89 & 0.99 & 1.18 & 1.25 \\
\hline & \multicolumn{5}{|c|}{ Net return: FL/MU (\$/acre) } \\
\hline 0.84 & $-3,280.66$ & 499.34 & $2,389.34$ & $6,169.34$ & $7,492.34$ \\
\hline 0.67 & $-2,293.30$ & $1,486.70$ & $3,376.70$ & $7,156.70$ & $8,479.70$ \\
\hline 0.54 & $-1,538.26$ & $2,241.74$ & $4,131.74$ & $7,911.74$ & $9,234.74$ \\
\hline 0.43 & -899.38 & $2,880.62$ & $4,770.62$ & $8,550.62$ & $9,873.62$ \\
\hline \multirow[t]{2}{*}{0.34} & -376.66 & $3,403.34$ & $5,293.34$ & $9,073.34$ & $10,396.34$ \\
\hline & \multicolumn{5}{|c|}{ Differences between the net return of FL/MU vs. those of FL ( $\$ /$ acre) } \\
\hline 0.84 & $-1,600.04$ & -734.04 & -301.04 & 564.96 & 868.06 \\
\hline 0.67 & -612.68 & 253.32 & 686.32 & $1,552.32$ & $1,855.42$ \\
\hline 0.54 & 142.36 & $1,008.36$ & $1,441.36$ & $2,307.36$ & $2,610.46$ \\
\hline 0.43 & 781.24 & $1,647.24$ & $2,080.24$ & $2,946.24$ & $3,249.34$ \\
\hline 0.34 & $1,303.96$ & $2,169.96$ & $2,602.96$ & $3,468.96$ & $3,772.06$ \\
\hline $\mathrm{B} / \mathrm{E}^{\mathrm{w}}$ & 0.56 & 0.71 & 0.79 & 0.94 & 0.99 \\
\hline
\end{tabular}

${ }^{2}$ Transplant costs derived by decreasing the highest cost $(\$ 0.84)$ by $20 \%$ gradually.

yTomato selling (shipping point) prices derived from average market prices of mature green tomatoes per $25-\mathrm{lb}$ ( $11.3 \mathrm{~kg}$ ) carton in the past 7 years (USDA, $201 \mathrm{l}$ ); $\$ 1.00 / 25$-lb carton $=\$ 0.0882 / \mathrm{kg}$.

$\times \$ 1.00 /$ acre $=\$ 2.4711 /$ ha.

${ }^{\mathrm{w}} \mathrm{B} / \mathrm{E}=$ break-even grafted transplant price, i.e., the price at which grafted and nongrafted tomato production would lead to the same net return, with varying tomato selling prices.

(Table 7). Theoretically, these values represent the maximum cost of grafted tomato transplants that a grower will accept to use grafted transplants. Overall, these break-even prices of grafted transplants increased with the increase in tomato selling price. Practically, it indicated that with the rising market tomato price, growers could be more willing to bear a higher cost of grafted transplants to obtain a higher net return in comparison with the nongrafted plants.

Although the high cost of grafted transplants remains the main barrier for wide adoption of vegetable grafting in the United States, results of this study in fumigated field in sandy soils showed that using grafted transplants is an economically viable practice that commercial tomato growers could potentially incorporate into their current production system. The margin of profit of grafted tomato production relative to nongrafted tomato production is more pronounced in the scenarios of reduced grafted transplant costs and increased selling prices for tomato fruit. In this study, tomato fruit size was not considered in the profitability analysis, which may deserve further assessment as grafting also led to an overall increase of average fruit weight (Djidonou et al., 2013). The fluctuation of tomato selling prices is oftentimes unpredictable; however, with research and technology advancement, it is expected that the cost of grafted transplants may be lowered in the near future. On the other hand, possible cost savings associated with grafted tomato production need to be fully evaluated. For instance, planting density may be reduced when using vigorous rootstocks given the yield improvement potential of grafted plants. According to RicárdezSalinas et al. (2010), with the use of grafted melon plants with no soil fumigation, planting density may be reduced by up to $60 \%$ as compared with nongrafted melon production with soil fumigation without compromising fruit yield. Limited information is available at present concerning the effect of grafting on plant population adjustment for cost reduction with different rootstocks.

In our study, the comparison of grafted and nongrafted tomato production was conducted in soils fumigated with 1,3-dichloropropene + chloropicrin, which allowed for evaluation of the grafting benefit for yield improvement beyond disease control. To provide a more complete analysis of economic feasibility for field production of grafted tomato, production systems with and without soil fumigation can be included in future studies that will help elucidate the economic returns associated with the effectiveness 
Table 7. Estimated net returns of field production of 'Florida 47' tomato grafted onto 'Beaufort' (FL/BE) and 'Multifort' (FL/MU) and the differences in net returns between grafted and nongrafted 'Florida 47' (FL) production with varying tomato prices and grafted transplant costs using the 2011 yield data.

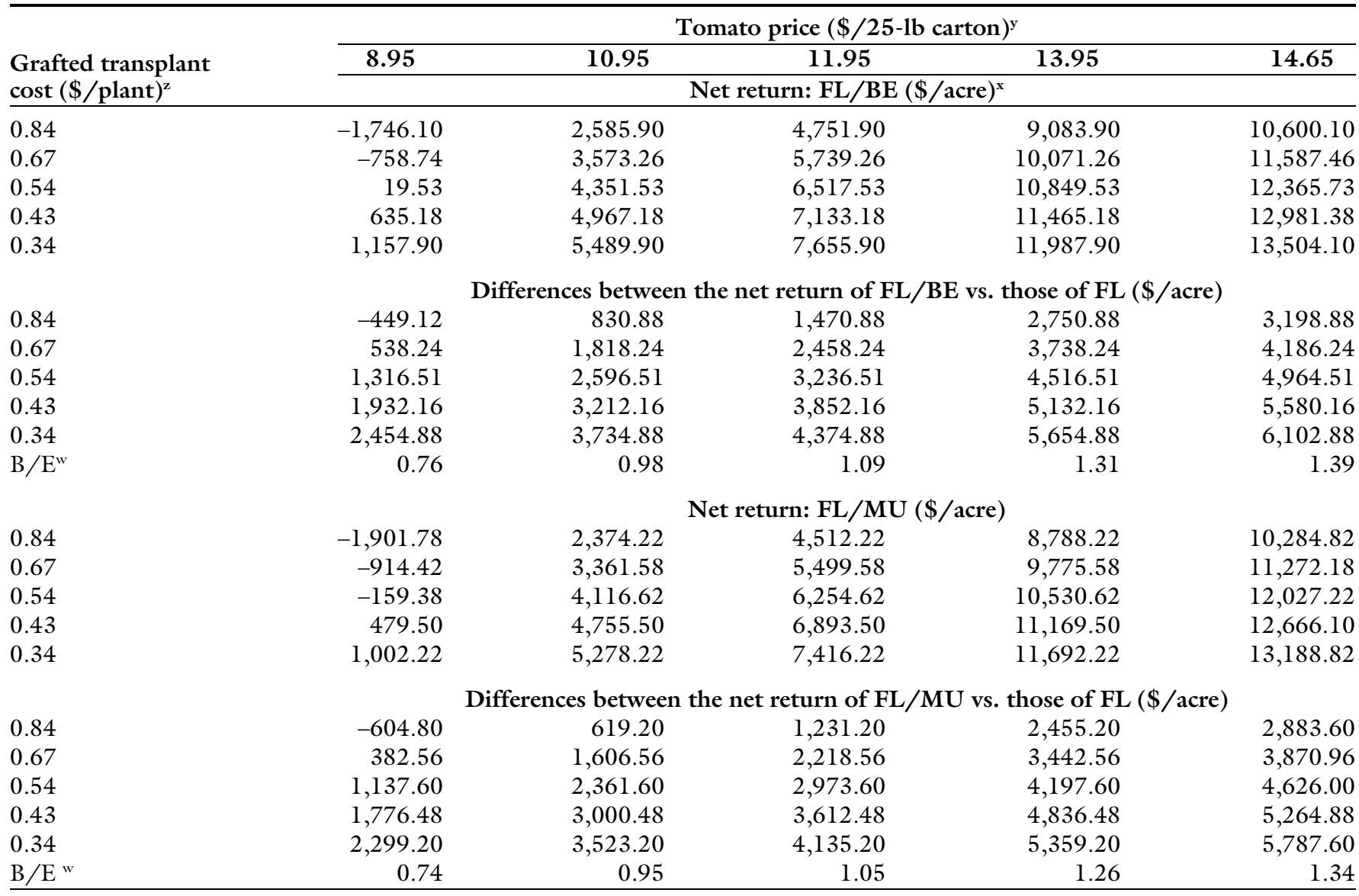

${ }^{2}$ Transplant costs derived by decreasing the highest cost $(\$ 0.84)$ by $20 \%$ gradually.

yTomato selling (shipping point) prices derived from average market prices of mature green tomatoes per 25 -lb ( $11.3 \mathrm{~kg}$ ) carton in the past 7 years (USDA, 2011 ); $\$ 1.00 / 25$-lb carton $=\$ 0.0882 / \mathrm{kg}$

${ }^{\times} \$ 1.00 /$ acre $=\$ 2.4711 /$ ha.

${ }^{\mathrm{w}} \mathrm{B} / \mathrm{E}=$ break-even grafted transplant price, i.e., the price at which grafted and nongrafted tomato production would lead to the same net return, with varying tomato selling prices.

of disease control vs. improvement of crop vigor and yield enhancement.

\section{Conclusions}

Growing grafted tomatoes demonstrated higher production costs due to the increased costs associated with grafted transplants and enhanced yield. In the field production with fumigated soils, the yield improvement with the use of grafted transplants led to higher returns that ultimately increased the net return as compared with the use of nongrafted transplants. More on-farm trials involving different tomato scion cultivars in commercial growing conditions are still needed to help growers decide whether grafting can be integrated as an economically viable component into their existing production systems. A complete set of scenarios for economic analysis needs to be considered to fully assess the costs and profits associated with using grafted plants for disease management, enhancement of irrigation water and fertilizer use efficiency, and yield improvement. Furthermore, the cost effectiveness of grafted tomato production is expected to increase with the higher tomato selling prices and, perhaps more importantly, the reduced costs of rootstock seeds and grafted transplants as a result of the future development of vegetable grafting research.

\section{Literature cited}

Barrett, C.E., X. Zhao, and R. McSorley. 2012a. Grafting for root-knot nematode control and yield improvement in organic heirloom tomato production. HortScience 47:614-620.

Barrett, C.E., X. Zhao, and A.W. Hodges. $2012 \mathrm{~b}$. Cost benefit analysis of using grafted transplants for root-knot nematode management in organic heirloom tomato production. HortTechnology 22:252-257.
Besri, M. 2003. Current situation of tomato grafting as alternative to methyl bromide for tomato production in $\mathrm{Mo}^{-}$ rocco. Proc. 12th Annu Intl. Res. Conf. Methyl Bromide Alternatives Emission Reductions, 31 Oct. - 3 Nov., San Diego, CA. 47:1-3.

Di Gioia, F., F. Serio, D. Buttaro, O. Ayala, and P. Santamaria. 2010. Influence of rootstock on vegetable growth fruit yield and quality in 'Cuore di Bue', an heirloom tomato. J. Hort. Sci. Biotechnol. 85:477-482.

Djidonou, D., X. Zhao, H.E. Simonne, K.E. Koch, and J.E. Erickson. 2013. Yield, water-, and nitrogen-use efficiency in field-grown, grafted tomatoes. HortScience 48:485-492.

Fernández-García, N., V. Martínez, A. Cerdá, and M. Carvajal. 2002. Water and nutrient uptake of grafted tomato plants grown under saline conditions. J. Plant Physiol. 159:899-905.

Gazula, A. 2009. Impact of irrigation and nutrient management programs on fruit 
yields, nitrogen load, and crop value of fresh market tomato grown with plasticulture in the era of best management practices. PhD Diss., Univ. Florida, Gainesville.

King, S.R., A.R. Davis, X. Zhang, and K. Crosby. 2010. Genetics, breeding and selection of rootstocks for Solanaceae and Cucurbitaceae. Sci. Hort. 127:106-111.

Kubota, C., M.A. Mcclure, N. KokalisBurelle, M.G. Bausher, and E.N. Rosskopf. 2008. Vegetable grafting: History, use, and current technology status in North America. HortScience 43:1664-1669.

Lee, J.M. and M. Oda. 2003. Grafting of herbaceous vegetable and ornamental crops. Hort. Rev. 28:61-124.

Lee, J.M., C. Kubota, S.J. Tsao, Z. Bie, P. Hoyos Echevarria, L. Morra, and M. Oda. 2010. Current status of vegetable grafting: Diffusion, grafting techniques, automation. Sci. Hort. 127:93-105.

Louws, F.J., C.L. Rivard, and C. Kubota. 2010. Grafting fruiting vegetables to manage soilborne pathogens, foliar pathogens, arthropods and weeds. Sci. Hort. 127:127-146.

O'Connell, S., C. Rivard, S. Hartmann, M. Peet, and F. Louws. 2009. Grafting tomatoes on disease resistant rootstocks for small-scale organic production. 1 May 2012. <http://www4.ncsu.edu/ clrivard/ OFRF_Final_Report.pdf $>$.

Olson, S.M., W.M. Stall, G.E. Vallad, S.E. Webb, T.G. Taylor, S.A. Smith, E.H. Simonne, E. McAvoy, and B.M. Santos.
2009. Tomato production in Florida, p. 291-312. In: S.M. Olson and E. Simonne (eds.). Vegetable production handbook for Florida. Inst. Food Agr. Sci., Univ. Florida, Gainesville, FL.

Pitts, D.J., A.G. Smajstrla, D.Z. Haman, and G.A. Clack. 2002. Irrigation costs for tomato production in Florida. Univ. Florida, Dept. Agr. Biol. Eng., Inst. Food Agr. Sci., Florida Coop. Ext. Serv., Publ. AE74, FL.

Ricárdez-Salinas, M.V., M. HuitrónRamírez, J.C. Tello-Marquina, and F. Camacho-Ferre. 2010. Planting density for grafted melon as an alternative to methyl bromide use in Mexico. Sci. Hort. 126:236-241.

Rivard, C.L. and F.J. Louws. 2008. Grafting to manage soilborne diseases in heirloom tomato production. HortScience 43:2104-2111.

Rivard, C.L., S. O'Connell, M.M. Peet, and F.J. Louws. 2010a. Grafting tomato with interspecific rootstock to manage diseases caused by Sclerotium rolfsii and southern root-knot nematode. Plant Dis. 94:1015-1021.

Rivard, C.L., O. Sydorovych, S. O'Connell, M.M. Peet, and F.J. Louws. 2010b. An economic analysis of two grafted tomato transplant production systems in the United States. HortTechnology 20:794-803.

Schwarz, D., Y. Rouphael, G. Colla, and J.H. Venema. 2010. Grafting as a tool to improve tolerance of vegetables to abiotic stresses: Thermal stress, water stress, and organic pollutants. Sci. Hort. 127:162171.

Sydorovych, O., C.D. Safley, R.M. Welker, L.M. Ferguson, D.W. Monks, K. Jennings, J. Driver, and F.J. Louws. 2008. Economic evaluation of methyl bromide alternatives for the production of tomatoes in North Carolina. HortTechnology 18:705-713.

Taylor, M., B. Bruton, W. Fish, and W. Roberts. 2008. Cost benefit analyses of using grafted watermelon transplants for fusarium wilt disease control. Acta Hort. 782:343-350.

University of Florida Center for Agribusiness. 2009. Spring tomatoes: Estimated production costs in the Manatee/Ruskin, FL area. 18 Apr. 2012. <http://fred.ifas.ufl. edu/iatpc/files/RuskinSpringTomato09. pdf $>$.

U.S. Department of Agriculture. 2011. Fruit and vegetable market news. 25 Apr. 2012. $<$ http://marketnews.usda.gov/portal/ fv?paf_dm=full\&paf_gear_id=1200002\& startIndex $=1 \& \mathrm{dr}=1$ \&rowDisplay Max = $50 \&$ displaySort $=\&$ navClass $=\&$ rep Type $=$ shipPriceDaily\&termNavClass $=$ \&shipNavClass= \&movNavClass $=$ \&loc $\mathrm{Name}=$ \&locAbr $=\&$ commAbr $=$ TOM\&comm Name $=$ TOMA TOES\&varName $=\&$ repDate $=07 \% 2 \mathrm{~F} 01 \%$ 2F2010\&environment $=$ \&organic $=\& \mathrm{x}=13 \&$ $\mathrm{y}=7>$. 